CATALAN REVIEW

Catalan Review

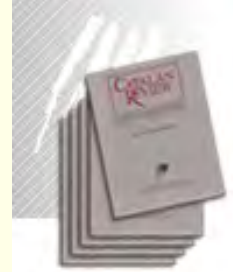

You are accessing the Digital Archive of the Catalan Review Journal.

By accessing and/or using this Digital Archive, you accept and agree to abide by the Terms and Conditions of Use available at http://www.nacs-

catalanstudies.org/catalan review.html

Catalan Review is the premier international scholarly journal devoted to all aspects of Catalan culture. By Catalan culture is understood all manifestations of intellectual and artistic life produced in the Catalan language or in the geographical areas where Catalan is spoken. Catalan Review has been in publication since 1986.
NORTH

AMERICAN

CATALAN

SOCIETY
Esteu accedint a l'Arxiu Digital del Catalan Review

A l' accedir i / o utilitzar aquest Arxiu Digital, vostè accepta i es compromet a complir els termes i condicions d'ús disponibles a http://www.nacs-

catalanstudies.org/catalan review.html

Catalan Review és la primera revista internacional dedicada a tots els aspectes de la cultura catalana. Per la cultura catalana s'entén totes les manifestacions de la vida intel lectual i artística produïda en llengua catalana o en les zones geogràfiques on es parla català. Catalan Review es publica des de 1986.

\title{
"Ab les mans junctes e genolls en terra": Intercession and the Notion of Queenship in Late Medieval Catalonia Dawn Bratsch-Prince
}

Catalan Review, Vol. XX, (2006), p. 211-228 


\title{
"AB LES MANS JUNCTES E GENOLLS EN TERRA": INTERCESSION AND THE NOTION OF QUEENSHIP IN LATE MEDIEVAL CATALONIA
}

\author{
DAWN BRATSCH-PRINCE
}

\begin{abstract}
Did medieval women who wore the crown share a common notion of queenship or recognize their own membership in a privileged group? Throughour medieval Europe the most salient images of queenship were those of wife, mother, and intercessor, familiar to the general population through Biblical and literary sources. This essay suggests that medieval Mediterranean queens were, in fact, aware of the power and influence that their role as intercessor afforded them. Two texts composed by the Aragonese queen Violant de Bar are used to shed light on a notion of queenship seemingly understood by her contemporaries, both male and female. The proemi or prologue of the queen's address on judicial reform to the Catalano-Aragonese corts generals of 1388 1389 and a lengthy letter (I42I) to queen María of Castile reference the responsibilities of the queen in mediating tensions and hostilities between the king and his rivals. From these documents, one gleans that queenship in early fifteenth-century Mediterranean Europe appears to have been viewed by its practitioners as a divinely-appointed office that entailed grave responsibility, as well as influence, by means of its emphasis on intercession.
\end{abstract}

\section{INTRODUCTION}

In her essay "Medieval Queenship," historian Janet Nelson takes issue with the assumption that "the queen's caring role -her petitioning and interceding - marginalized and contained her, keeping her out of the political arena and illustrating the deterioration of women's status in the wake of the development of patrilineage and more clear cut inheritance rules of male primogeniture" (20I). Nelson, together with historians Lois L. Huneycutt and John C. Parsons, suggests a more positive view of this "petitioning and interceding," calling it a powerful tool in the hands of an intelligent queen, a tool that served "as a perfect foil for and complement to" the stubbornness or harshness of a king (20I).

There is general agreement that there was no "uniformity" in the shape of queenship in the medieval Mediterranean. The queen was queen by virtue of her relationship to the person of the king, and kingship was shaped by chronology and geography, hence queenship evolved in a unique manner in distinct regions. Gender served as the 
one unifying factor among these distinct manifestations of queenship, for it was a gendered office. A queen's experiences, according to Nelson, "were those of all women: she moved spatially from one family into another and moved temporally through the phases of her life -into fertility, through motherhood, and into the sterility of old age" (Nelson 205). A second factor underpinning the shape of queenship was its highly personalized nature. A woman's land of origin, the social and economic disposition of her kin, her sexuality, the phases of her life, the temperament of the king, were all personal matters which greatly influenced her public posture. As both a daughter and, subsequently, a wife, she became an intermediary between two families and two kingdoms. By the later Middle Ages, this "power to straddle, to intercede, to set personal influence against official authority, was the queen's defining trait" (Nelson 205).

As scholars of the twenty-first century, we speculate, generalize, and seek to identify other methods of characterizing the office of the queen. One question that remains to be answered, if that is indeed possible, is whether or not medieval women who wore the crown shared a common notion of the loosely-defined term "queenship"? Did they recognize among themselves their membership in a special and privileged group? Historian Lois Huneycutt, seeking to answer these questions for late-eleventh and early-twelfth century England, confronts the difficulty that such questions provoke because "[w]e are limited by the paucity of sources that reveal the self-image of any medieval female" (1995, 131). Although the notion of institutionalized queenship is one that has taken root only in the modern era, ${ }^{1}$ I believe that medieval women did in fact share an understanding of the expectations inherent in the notion of queenship. The most salient images of queenship, primarily those of wife, mother, and intercessor, were familiar to the general population through Biblical and literary sources, the latter of which included chronicles, hagiographical texts, romance, epic, and courtly poetry, which often offered up the Virgin Mary or the Hebrew prophet Esther as the premiere models of queenly virtue. ${ }^{2}$

Culling through the extant correspondence of the queens of the Crown of Aragon at the turn of the fifteenth century, one finds a rich

I Nelson (179) argues that while the notion of queenship is modern, by the middle ages women had developed an understanding of the characteristics of and expectations for a queen largely transmitted through literary texts. Curiously, neither the Spanish nor the Catalan languages have ever developed a precise term for "queenship." In her 2003 article, Núria Silleras-Fernández explores the absence of a precise term in Spanish or Catalan for "queenship" and proposes the terms "reginalidad" and "reginalidat."

2 See Huneycutt $(1989,1995)$ for studies of the image of queenship in early medieval Great Britain. 
written record of how these women petitioned, pleaded, and interceded, seeking to influence and achieve favor from the men around them. For these women, the queen's role as intercessor does not appear to have "marginalized and contained her," but rather, as Nelson suggests, to have empowered her, as we see, for example, in the political lives of Aragonese queens Violant of Bar (1365-1431), María of Luna (1358-1406), and María of Castile (1401-1458). This essay suggests the existence of an awareness of the power of queenship among a group of medieval Mediterranean queens in which they held as pivotal their role as intercessor and the influence it afforded them. To support this contention, I shall refer to two texts composed by queen and eventual dowager, Violant de Bar, in which she lends form and color to a notion of queenship seemingly understood by her contemporaries, both male and female. The first of these texts is the proemi or prologue of the queen's address on judicial reform to the CatalanoAragonese corts generals of ${ }_{1388-1389}$ (Appendix I) translated here into English for the first time. In the proemi we see embedded a literary evocation of the duties of the medieval queen. The natural development of this notion and its acceptance and application beyond the borders of the Aragonese Crown are found subsequenly in a lengthy letter to the reigning Aragonese queen, María of Castile, dated I42I (Appendix 2). This second document references the responsibilities of the queen in mediating the on-going hostilities between the Aragonese and Angevines in Naples. From these documents, one gleans that queenship in early fifteenth-century Mediterranean Europe appears to have been viewed by its practitioners as a divinely-appointed office that entailed grave responsibility, as well as influence, by means of its emphasis on intercession.

\section{The Proemi}

When Joan I suceeded his father, king Pere III, to the Catalano-Aragonese throne in early 1387 , he was obliged by the gentlemen and nobility of his kingdom to reconvene the corts generals or parliament, which he did in Zaragoza on September 7, 1388. ${ }^{3}$ Among the more pressing and volatile issues to be taken up by the corts were the

3 The corts generals were convened by petition of the king or the representatives of the realm to treat matters of state and to deal with issues of land reform (Coroleu and Pella $2 \mathrm{~N}$ ). The corts referenced here had been convened originally by Pere III in 1383 in Montço, but had never been formally closed. Albert and Gassiot (251) give the closing date of the corts as November 3,1389 in Montço. These corts were the only ones ever convened by Joan I, and they were never formally concluded, rather unofficially suspended in $138 \%$. 
accusations of corruption in the casa reial and a concomitant need for serious judicial reform. ${ }^{4}$ Joan presented his proposed articles on the reform of judicial administration in November. The following March the corts rejected the proposition, counter-proposing another plan, which the king then promptly rejected. As the weeks and months wore on, it became clear that neither side would come easily to a compromise while the king threatened with drastic measures, as historians Coroleu and Pella note:

Como [el rey] hubiese presentado tambien aquellos dias varios proyectos de Constituciones relativos â la administracion de Justicia, quisiseron las Córtes enmendarlos y aumentarlos, pasando en ellos muchos dias, por lo cual se vió el Rey obligado á decirles que si continuaban las dilaciones se pondria al frente del ejército para ir á recibir al enemigo, cargando los diputados con toda la responsabilidad de lo que por su negligencia ocurriese (2II).

[Since [the king], too, had presented during that time various constitutional projects related to the administration of justice, the Cortes wanted to emend them and amplify them by spending many days on them, for which reason the king found himself obliged to tell them that if the delays continued, he would place himself at the head of the army ready to meet the enemy, placing all the responsibility for whatever would happen on the deputies because of their negligence.]

Sensing that no solution could be found otherwise, Queen Violant determined to intervene in the stalemate between the king and the corts. She drew up nine articles of compromise reform, which she then presented orally before the corts with a brief prologue that began:

For some time now, we have lain awake and thought so much [about this matter] that we have almost passed the nights in sleeplessness, [in the hope] that God, from whom all good comes and whose hands sustain the king's heart, in His grace might give us a path and manner by which we might bring to consensus you who are here from all the kingdoms in the present general corts with the lord king, our most dear lord and husband.

With this humble evocation, the queen introduced her proposal which was quickly accepted by the corts, and, despite initially finding the proposed compromises "carregosos" or troublesome (Albert and Gassiot 25I), by the king as well. Coroleu and Pella, who document the legislation enacted, strongly applaud the intervention of the queen in this negotiation and acknowledge that she "with such opportune discretion knew how to play the role of peace-maker between the

4 Intrigue in the Aragonese royal household had long been a source of tension between the corts and the monarchy. 
pride of her effeminate husband ${ }^{5}$ and the jealous arrogance of the Cortes, and by doing so saved the public peace at the same time as the dignitiy of the royal marriage bed" (Coroleu and Pella 406).

In her eloquent prologue [Appendix $\mathrm{I}$, Violant begins by justifying her political intervention in the matter of the corts as well as her efforts to ratify a compromise. She defends her actions by articulating her own conceptualization of what the role or duty of a queen is to be. She identifies three justifications for her intercession:

And three principal things have led us to this: the first, that we are indebted to God who in His mercy has joined us to the aforesaid lord; the second, that it is an office that He has entrusted unto us, which is that whenever we see discord between the aforesaid lord and you, we might work incessantly to turn it into harmony, for thus acted the valiant empress of most esteemed memory, Augusta, who humbly and continually begged the emperor that he leave aside iniquity and rancor toward the people of his empire and that justice, charity, benevolence, and love be with him [instead]; the third, that great infamy will be the king's and yours, because you did not agree upon anything, such that both neighboring kings and other peoples of the world would have much to speak about, so much that it would be an offense to his royal dignity and your vassallage and loyalty, which surmounts all others, would not be doing what it is wont to do.

Through her use of imagery, Viólant presents queenship as a divinely santioned "offici" or responsibility, based on her marital union with the king. As the king's wife, the queen took on the role of helpmate and intercessor, a model that traces itself back to the image of that other divinely sanctioned wife, Mary. The queen, she posits, has an obligation to God to take action in matters of concern to the king, for He has joined her with the king as helpmate. As a queen, she maintains that she has been commended by God into service as intermediary between the king and his vassals. In this proemi, Violant chooses to liken her actions here to those of an early empress of the Roman Empire, possibly Livia Augusta, ${ }^{6}$ a model of temperance, fairness, and stability, who,

${ }_{5}$ Because of his exquisite taste in fancy goods, hunting, and books, Joan I became known as "Amador de la gentilesa." His ineffective leadership and preoccupation with finery coupled with Violant's ambitious involvement in political circles earned him the reputation of an effeminate husband (See Tasis i Marca 1959; Bratsch-Prince 2004, 2006).

6 While there is no record of an empress named Augusta, the term is frequently used to refer to Livia Drusilla, the wife of Octavian, the first emperor to use the title Augustus. Medieval sources of information on the Roman emperors would have been either Valerius Maximus or Suetonius, with the former being the most widely accessible in medieval Iberia. The inventory of Aragonese king Marti I (Massó i Torrents rgos) lists a copy of a Catalan translation of Valerius Maximus (437, \#169) and Miquel i Planas (t9r4) dates Antoni Canals' translation of Valerius Maximus to some time before 1395. 
according to historical accounts, was also forced to mediate between her husband and his subjects. Furthermore, as a woman, it falls to the queen to look after the good name of the family and the royal household. Queen Violant insists that she must intervene in the corts for fear of what neighboring kings might conclude regarding the king's authority if a stalemate were to continue between him and his subjects. As the figurehead of the king's household, the queen must prevent any damage that such gossip might inflict on the realm's honor.

As she speaks to the corts, Violant conjures a visual image of her humbled self before the king, "with our hands together and our knees to the ground." In employing the image of the queen in prayerful contenance, hands together in supplication and knees to the ground as if before God, Violant seek to soften the king:

we have begged the king that in his grace and mercy, and out of consideration for us, he open the door of his kindness which has been closed because of the merits of some, just as was the door of Paradise because of the sin of Eve.

By considering or contemplating her image, she asks the king to "open the door of his kindness."

The "republic," according to Violant, will "remain in prosperity and notable defense, " only if each constituency knows its place and faithfully fulfills its duty. She uses the crown as a symbol of regal power and authority. In this hierarchy, her duty is to maintain the peace and stability of the nation through her intercession. Violant clearly presents herself publicly as wielding considerable influence with the king through whom she acknowledges she receives validation and power for herself.

\section{LATER VALIDATIONS OF QUEENSHIP}

Through her proemi, Violant articulates a vision of the power and authority invested in the office of the queen by means of the queen's access to and influence with the king. Some twenty-five years after the death of her husband, Violant again takes up some of the notions and images of queenship that she so effectively presented to the corts in 1389 , this time in a letter addressed to María of Castile, queen of Aragon. In this missive, the widowed Violant pleads with the reigning Aragonese queen and lieutenant general to persuade her husband, Alfonso V, to rescind his claims to Naples. Violant once again invokes the moral responsibilities of a queen to influence and persuade the king in times of necessity.

In many respects, the thirty-five years of Violant's widowhood 
(1396-1431) are the most telling of her quest for influence and power, despite a general assumption that the king's death would effectively terminate and silence the influence of the queen. Without the expectations of her office, the needs of her sickly husband, nor the demands of her in-laws and the corts, Violant was free to act out as she chose. She was, however, fully cognizant of the fact that " $[t]$ he power of a medieval queen rested on a perception of influence rather than any institutional base, and the loss of that perceived influence could spell disaster" (Nelson 194). To paraphrase Huneycutt (1995), with little and disputed income of her own, no husband over whom to exercise her influence, and only one surviving child, a daughter, Violant had little prospect of winning allies at court or maintaining any meaningful control over her fate. Seeking to avoid the disaster of political irrelevance, Violant carefully buoyed her queenly image by keeping alive the memory of her husband and his male descendents, and in this way aligning herself with the specter of male authority. The widowed queen, once again serving as the connection between two kingdoms, Aragon and Anjou, now identified herself as mother of the queen of Sicily and Jerusalem, Violant of Aragon, and grandmother to Louis III of Anjou, for, like others in her position,"at the very least, as dowager and grandmother, she could be an influential figure" (Nelson 194).

In May I421, Violant had just returned from a year's sojourn in Provence where she had spent time with her daughter, Violant of Aragon (1381-1442), the widow of Louis II d'Anjou (d. 1417) and former duchess of Anjou, queen of Sicily and Jerusalem, and titular queen of Naples. Violant also spent time with her grandchildren, Louis III, duke of Anjou (1403-I438); Marie, future wife of Charles VII of France; and René (1408-1480). The period from 14I9 to 1423 was a volatile one for Aragonese-Anjou relations and Violant would have found herself in the thick of things during her visit.

During the reign of queen Joanna II of Naples (1414-I435), many Neapolitan nobles looked to Aragon for their survival and defense, for the elderly queen, by this time, was according to Ryder "an impossible woman, devoid of political sense and moral character" who "wallowed helplessly in the sea of intrigue that surrounded her, grasping at one expedient after another and casting each aside as it became irksome to her" (23). As queen, Joanna was unable to maintain stability in her factious kingdom or defend Neapolitan sovereignty from "rival claimants" (Ryder 23). By this point, Joanna had neither a consort nor any offspring to support her rule. In between disastrous and barren marriages, Joanna proposed a marital union with the second son of Fernando I of Aragon before quickly rescinding the offer. (Her would-be suitor was thirty years her junior.) In November 1420, pope Martin V, "anxious to reinforce the authority of the Neapolitan throne 
by the presence of a legitimate heir and also to re-establish the papacy in Rome" backed the claim of Louis III to the throne of Naples (Ryder 24). Joanna turned to the Aragonese for help, proposing that Alfonso V (I4I6-1458) become her adopted heir and defender against the Angevines. While the Aragonese people and the king's counsellors advised against complicity in this never-ending and dangerous matter, Alfonso chose to become involved (Ryder 25).

Aspiring to influence the politics of the Aragonese monarch, Violant wrote to the queen in May I421. María wielded much authority as lieutenant general of the realm ${ }^{7}$ during the absences of her husband, yet Violant writes to her in her capacity as queen, urging that she convince the king to retreat from Naples in preservation of peace with Louis III. The dowager queen's letter presents a fascinating example of a femenine world view, since the frame of reference is entirely female: the dowager queen of Aragon, Violant, writes to the reigning queen of Aragon, Maria of Castile, on behalf of her own daughter, the queen of Naples and Sicily, and against Joanna II, queen of Naples. While the frame of reference is female, the purpose of the intervention proposed by Violant is to influence and alter the actions of men. Violant positions her legitimacy to intercede in these political affairs within the network of familial relations, as she writes:

Dear and most beloved granddaughter, through the letters of our most beloved daughter, the queen, ... we have seen and understood how our said daughter, the queen, has sent to you [...] deliverers and ambassadors [...] out of her great desire that between our dear grandson, the king, your husband, and our dear son and that of the said queen our daughter, king Louis, there might be peace, friendship, and agreement, just as ought to be expected between two people who proceed from one house and one blood.

As she works to persuade María of the necessity for intervention, Violant provides a most concrete acknowledgement of the significance of intercession for queens, insisting to Maria the obligation of mediation:

it is your very office and it is a habit worn well by all queens, and we know this, we who have lived it. And for this reason, we, and the said queen, our

7 According to Theresa Earenfight the office of lieutenant-general, to which María was first named in May 1419, "originated in the thirteenth century as a practical means of ruling the extended territorial possessions of the Crown of Aragon. The lieutenant was a member of the royal family, male or female, and over time the office had become the traditional training ground of the princes" (50-5I). Maria's role in the governance of the Crown of Aragon has long been ignored by historians who have preferred to write about her cultural endeavors. See Earenfight (1994, 1997, 2003) ) for more detailed accountings of María's responsibilities and actions as lieutenant general. 
daughter, wanting to wear the said habit, want to inform and explain to you the said things, and of them communicate as much as we can. Beseeching, requiring, and warning you again, with the insistence that it deserves, that, because of the said considerations and for the rest of so many people, and for the edification and instruction of so many benefits which cannot yet be seen, since human thoughts and eyes are not sufficient enough to do so, in this you please think and work quickly, and among the other worries that you have in the governing of this realm, you see to this one, which will be most acceptable to God, and by which you will earn great fame in the world.

The dowager queen takes up once again the image of queenship as an office or profession, with weighty moral responsibility. ${ }^{8}$ Intercession, in Violant's rhetoric, is "a habit worn well by all queens," an image that suggests a religious cloak of moral obligation that all queens must don. The image of the "habit" serves as a uniform that identifies and unites all queens who profess the "vows" required to wear it. Violant stakes her claim for inclusion in this elite group by virtue of her past experience ("sabem-ho nós qui'n som passada"), claiming that she and her daughter want to dress in that regal robe and virtuous habit of queenship, and they invite Maria of Castile to do the same.

Equally significant in identifying a shared notion of queenship, is what Violant poses as antithetical to proper queenly behavior, personified in this instance in the person of Joanna II, singled out as "una sola dona fora de parentiu e no coneguda, ne zelant la honor d'aquesta casa d'Aragó, segons experiencia ha demostrat en nostre dies, mes solament per son propia interes e barat." Joanna does not belong to their family, nor to any family for that matter in Violant's rhetoric. Outside of the blood-line of the house of Aragon, Joanna was an unknown ("no coneguda") and unfamiliar entity ("fora de parentiu"). Furthermore, she had not proven herself to be a reliable queen for she had neither husband nor heirs, Rather than serving as a mediator and intercessor, as was her moral obligation as queen, Joanna worked "to sow darnels and discord" between the kings. She was a creator of divisions and, in the words of Violant, servant to a "diabolical order" and perceived to be working against "reason and justice" which sought to make the kings "of one heart and one will."

In this letter, we have a three-way call to intercession. Violant de Bar, Violant of Aragon, and María of Castile, are assumed to share a common understanding of the type of intervention expected of and allowed to each. While all three noblewomen appear to have understood the obligation of intercession, each had distinct and extenuating

8 Coromines (DECLC 3: 964 "Fer") glosses "ofici" as both a practical activity ("servei, funcio," "ocupacio profesional") and as an activity entailing some moral overtones ("óbligació de treball," and "deure moral"). 
circumstances which constrained their degree of influence: Violant as dowager without male heir; Violant of Aragon as dowager and regent; María as reigning queen and, in her husband's absence, lieutenantgeneral; Joanna as an elderly reigning queen without consort or issue. We can see the complicated nature of medieval queenship, which may preclude any attempt to devise one theory.

These two documents are valuable in that, while representing one woman's conceptualization of the role and responsibilities of queenship, they also suggest that among Mediterranean queens there existed a common notion of the expectations inherent in this office. These women understood their responsibilities and the enormous, albeit constrained, power they could wield, "ab les mans junctes e genolls en terra," by means of intercession among and influence on their male kin. As Violant so vividly articulates, the influence of the queen held the potential to change the course of political events, such that, as Nelson concludes, "There was no safe queen like a dead queen" (206).

DAWN BRATSCH-PRINCE IOWA STATE UNIVERSITY 


\section{APPENDIX I}

\section{A. Catalan text of the "Proemi dels capitols presentats per la reina Violant a les corts de Montçó, el 28 de juny de $1389 . "$}

The original text was first edited by Ricard Albert i Joan Gassiot in Parlaments a les Corts Catalanes (Barcelona: Els Nostres Clàssics: 1928. 56-58). The edition reproduced here is that published by Rafael Tasis i Marca in Joan I. El rei caçador i músic (Barcelona: Editorial Aedos: 1959,164-65), which I chose because of its standardized orthography, utilization of modern punctuation, and readability.

"Nós llongament havem vetllat e cogitat, que quaix les nits havem duites en somnis, per ço que Déus, de qui tots vénen e en la mà del qual lo cor dels Reis és per sa gràcia, nos volgués dar via e manera que poguéssem concordar e avenir vosaltres, qui per los Regnes sots ací en la present Cort general ajustats ab lo senyor Rey e marit nostre molt car.

E han-nos-hi induhida tres principals coses. La primera, que som tenguda a Déu, qui per sa mercè nos ha associada al dit senyor. La segona, que és offici que ens ha comanat, lo qual és que tots temps que vejam discôrdia entre lo dit senyor $\mathrm{e}$ vosaltres incessantment treballem per reduir-ho en concòrdia. Car així ho faia aquella valent Emperadriu, de molt alta recordació, Augusta, qui humilment e continuada suplicava l'emperador que iniquitat e rancor fossen lluny d'ell vers les gents de son imperi e que justícia, caritat, benignitat e amor li fossen aprés. La terça, que gran infámia seria del senyor Rey e de vosaltres que no us concordàssets, de què haurien molt que parlar los Reys circumvicins e altres gents del món, tant que seria ofesa la dignitat reyal e vostra naturalesa e lleyaltat, qui sobrepuja totes altres, no faria ço que ha acostumat de fer.

Per què, tan devotament e humil com havem pogut, ab les mans junctes e genolls en terra havem lo dit Senyor Rey supplicat que ell per sa gràcia e mercè la sua porta de benignitat que era tancada per mérits d'alguns, així com fo aquella del paradís per lo pecat d'Eva, vulla per contemplació nostra obrir. Si que lo dit senyor, per sa gran clemència, l'ens ha oberta; en tant que havem aportat als capítols devall escrits, lo quals són d'estilers tals, que si havets la consideración de sana pensa, faets tals coses vers lo dit senyor que Déu ne serà pagat e la cosa púbila ne remandrà en bon estament e notable defensió, e sostendrets ell segons que sa magnificència requer, e exalçarets sa corona en la forma que us és degut e us han lleixada vostres predecessors.

E en los dits capítols no demanets us, car no ho obtindríets ne us aprofitaria; car diu Sul la el gran que qui ha obtenguda assenyalada grà- 
cia, aprés d'aquella demanar més és així una impertinent cosa, com escriure lletres sobre glaç."

\section{B. English translation of the "Proemi" prepared by Dawn Bratsch- Prince and based on the edition of Tasis $i$ Marca (1959).}

For some time now, we have lain awake and thought so much [about this matter] that we have almost passed the nights in sleeplessness, [in the hope] that God, from whom all good comes and whose hands sustain the king's heart, in His grace might give us a path and manner by which we might bring to consensus you who are here from all the kingdoms in the present general cort with the lord king, our most dear Jord and husband.

And three principal things have led us to this: the first, that we are indebted to God who in His mercy has joined us to the aforesaid lord; the second, that it is an office that $\mathrm{He}$ has entrusted unto us, which is that whenever we see discord between the aforesaid lord and you, we might work incessantly to turn it into harmony, for thus acted the valiant empress of most esteemed memory, Augusta, who humbly and continually begged the emperor that he leave aside iniquity and rancor toward the people of his empire and that justice, charity, benevolence, and love be with him [instead]; the third, that great infamy will be the king's and yours, because you did not agree upon anything, such that both neighboring kings and other peoples of the world would have much to speak about, so much that it would be an offense to his royal dignity and to your vassallage ${ }^{2}$ and loyalty, which surmounts all others, would not be doing what it is wont to do.

So, as devoutly and humbly as we have been able to, with our hands together and

our knees to the ground, we have begged the king that in his grace and mercy, and out of consideration for us, he open the door of his kindness which has been closed because of the merits of some, just as was the door of Paradise because of the sin of Eve. Just as the said lord in his great clemency has opened it for us, so we have brought the articles written below, which are of such a style that if you are able to consider them rationally you will do such things toward the aforesaid lord that God will be satisfied and the Republic will remain in prosperity and notable defense; and you will sustain him as his magnificence requires, and you will exalt his crown in the form that you ought to, just as your predecessors did.

9 Catalan "naturalesa" is here translated as "vassallage" based on Coromines' (DECLC 5: 905 'Néixer') definition of "naturalesa" as a feudal juridieal term that describes "una relació mútua de senyoria i vassallatge." 
And from the said articles do not demand any more, for you will not obtain it, nor would it profit you, for as Sulla the Great ${ }^{\mathrm{to}}$ said: "He who has obtained notable favor, should he demand still more, does an impertinent thing, just as if he were to write letters on ice."

\section{APPENDIX II}

A. Letter from Violant de Bar, dowager queen, to Maria de Castilla, queen of Aragon, explaining to ber the role and responsibilities of a queen, and asking for her belp in establishing peace between Aragon. and Anjou over the matter of Naples.

Arxiu de la Corona d'Aragó, reg. 2053, fol. ro6r. Barcelona, May 6, I42I.

A la molt excel-lent princessa molt cara emolt amada neboda, la senyora reyna [d'Aragó].

Molt excel-lent princessa molt cara e molt amada neboda:

Desijans continuament saber vostre bon stament de sanitat, vos pregam lo més que podem que a nostra consolació nos en vullats scriure totes hores que avinent vos serà, e serà cosa que us grayrem que més no poriem. Si de nós, molt cara e molt amada neboda, vos plau saber, vos certificam que a la faycó de aquesta nós som en bon punt de nostra persona, la mercè de Deu.

Molt cara e molt amada neboda, per letres de nuestra molt cara filla, la reyna, per report dels portadors de la present, sos ambaxadors, havem vist e entès com la dita nostra filla, la reyna ${ }^{11}$ tramet a vós los dits portadors ambaxadors, e açò per lo gran desig que ha que entre nostre car nebot, lo rey, marit vostre, ${ }^{12}$ e nostre car fill e de la dita reyna, nostra filla, lo rey Luis, ${ }^{13}$ hagues pau, amistat, e concordia, segons deu haver e's pertany entre dues persones de una casa e de una sanch procehins.

E no contrastant, molt cara e molt amada neboda, que'l enemich antich haje treballat e treballe ab sobirana vigilia sembrar zizanias e discordias entre los dits reys per mantenir la injusticia de una sola dona

ro Also known as Lucius Cornelius Sulla Felix (b. 138 ), Roman dictator from $83-80$ BCE. In $8 \mathrm{r}$ BCE he enacted a series of legislative reforms designed to put more power in the hands of the senate. In the pages of Valerius Maximus, he is remembered as a particularly cruel and vicious dictator.

It Violant of Aragon, widow of Louis II, Duke of Anjou (1377-1417), Duchess of Anjou and Titular Queen of Sicily and Jerusalem.

12 Alfonso V of Aragon (1396-1458).

13 Louis III, duke of Anjou (1403-1434) 
fora de parentiu ${ }^{14} \mathrm{e}$ no coneguda, ${ }^{15}$ ne zelant la honor d'aquesta casa d'Aragó, segons experiencia ha demostrat en nostres dies, ${ }^{16}$ més solament per son propi interes e barat, ${ }^{17}$ nós e la dita reyna, nostra filla, confiam en Deu, qui és deffenedor de justicia e del qual tots bens proceeixen, que Ell, pervertint l'orde diabolical, no permetrà que la dita zizania si mete rahils entre los dits dos reys, ans per sa infinida clemencia farà aquells de un cor e de un voler, segons dicten rahó e justicia.

Per ço, molt cara e molt amada neboda, nós, qui les dites coses desijam superlativament, segons sab Déu, e lo rey, nostre car nebot, e vós e tot lo mon han e haveu pogut veure e conexer, vos pregam, ab tanta affecció com dir se pot ne scriure que oynt los dits ambaxadors vos placia virtuosament e per obra treballar que entre los dits dos reys haje pau, concordia, e amistat, segons deu e és rahonable. En açò, molt cara e molt amada neboda, deveu-vos ab sobirana voler e studi treballar per molts esguarts, ço és per servei de Déu, a qui pau és acceptable entre los altres sacrificis e per esguard del dit rey, vostre marit, a qui de la dita pau se segueix repos e la qual ell e tots reys deven abraçar per descarrech de llurs consciencias e per repos de llurs vassalls.

Açò, molt cara e molt amada neboda, és propi a offici vostre, e és $a b i t^{18}$ molt bé ornant totes reynes, e sabem-ho nós qui'n som passada. E per aquesta rahó nós e la dita reyna, nostra filla, volens-nos vestir lo dit abit, volem les dites coses manifestar e notificar a vós e de aquellas comunicar tant com possible nos serà. Pregans, requerins, e amonestans-vos altre e altre vegada, ab aquella instancia que s pertany, que per los dits esguarts e per repos de tantes persones, e per edifficació e instrucció de tants benificis qui a present no 's poden preveure com penses e ulls humanals no y sien bastans, en açò vos placia prestament pensar e treballar, e entre les altres cures que havets de la governació d'aquest regne avistar-hi aquesta, la qual serà a Déu molt acceptable, e per la qual aconseguirets gran renom en lo mon.

$\mathrm{Si}$ algunes coses, molt cara e molt amada neboda, vos plaen que nós façam, nós les farem de molt bon car. E havem lo Sant Spirit, beneyt Fill de Déu, en sa comanda.

I4 The term "parentiu" is glossed in Coromines (DECLC 6: 294 "parir") as "nom collectiu i abstracte de la relació interfamiliar" that points more precisely to "parentiu per sang."

15 Joanna II of Naples.

I6 The "experiència" that Violant refers to here is Joanna's initial acceptance and subsequent rejection of a marriage proposal with the second-born son of Fernando I of Aragon.

17 In this sense "barat" seems to imply trickery.

18 The term "(h)àbit" can signify "custom" as well as clothing or an outfit, both definitions being acceptable in this context. 
Dada en Barcelona a vi. dies de maig en l'any de Nostre Senyor de .M.cccc.xxi.

La reyna Y[olant].

\section{B. English Translation of Arxiu de la Corona d'Aragó, reg. 2052, fol. 106r, prepared by Dawn Bratsch-Prince.}

To the most excellent and most dear princess and most loved granddaughter, the lady queen [of Aragon].

Most excellent and most dear princess and most loved granddaughter:

With the desire to continually know of your good state of health, we beg you as much as we can that for our consolation you write to us about it whenever it is convenient, and we will thank you for this as much as we can. If it please you, most dear and most beloved granddaughter, to know about us, we certify that at the writing of this we are in good health, thanks be to God.

Dear and most beloved granddaughter, through the letters of our most beloved daughter, the queen, and by the report of the deliverers of the present letter, who are her ambassadors, we have seen and understood how our said daughter, the queen, has sent to you the said deliverers and ambassadors, which she does out of her great desire that between our dear grandson, the king, your husband, and our dear son and that of the said queen our daughter, king Luis, there might be peace, friendship, and agreement, just as ought to be expected between two people who proceed from one house and one blood.

And notwithstanding, most dear and most beloved granddaughter, that the ancient enemy has worked and still works with supreme vigilance to sow darnels and discord between the said kings in order to maintain the injustice of one woman, an unknown and of no familiar affinity, who does not desire the honor of this house of Aragon, as experience has shown in our day; but rather her own interest and trickery, we and the said queen, our daughter, trust in God, who is defender of justice and from whom all good comes, that he, perverting the diabolical order, will not permit the said darnel to put barriers between the two aforesaid kings, but rather through his infinite clemency he will make them of one heart and one will, according to reason and justice.

For this reason, most dear and most beloved granddaughter, we, who the said things desire above all others, as God knows, and the king, our dear grandson, and you and everyone have been able to see and know, we beg, with as much affection as can be said or written, hearing the said ambassadors it please you to work virtuously and by 
deed so that between the said kings there might be more agreement and friendship, just as there ought to be and is reasonable. In this, most dear and most beloved granddaughter, with sovereign will and determination you ought to work for many considerations, namely for service to God, to whom peace is acceptable among other sacrifices, and for consideration of the said king, your husband, for whom rest will follow the said peace, which peace he and all kings ought to embrace for ease of their conscience and for the rest of their vassals.

Thus, most dear and most beloved granddaughter, it is your very office and it is a habit worn well by all queens, and we know this, we who have lived it. And for this reason, we, and the said queen, our daughter, wanting to wear the said habit, want to inform and explain to you the said things, and of them communicate as much as we can. Beseeching, requiring, and warning you again, with the insistence that it deserves, that, because of the said considerations and for the rest of so many people, and for the edification and instruction of so many benefits which cannot yet be seen, since human thoughts and eyes are not sufficient enough to do so, in this you please think and work quickly, and among the other worries that you have in the governing of this realm, you see to this one, which will be most acceptable to God, and by which you will earn great fame in the world.

And if there is anything that we can do for you, most dear and most beloved granddaughter, we will do it with all our heart. And we have commended you unto the Holy Spirit, blessed Son of God.

Given in Barcelona on the $6^{\text {th }}$ day of May in the year of Our Lord 1421.

Queen Y[olant].

\section{WORKS CITED}

Albert, Ricard, and Joan GAssiot, eds. Parlaments a les corts catalanes. Barcelona: Elis Nostres Clàssics, 1928.

Arxin de la Corona d'Aragó, Registres de Cancel'leria, 2052.

BratsCh-Prince, Dawn. Vida y epistolario de Violante de Bar (13651431), duquesa de Gerona y reina de Aragón. Biblioteca de Mujeres. Madrid: Ediciones del Orto, 2002.

- "The Politics of Self-Representation in the Letters of Violant de Bar (1365-1431)." Medieval Encounters 12 (2006): 2-25.

-. "Dones que feyan d'homens': The Construction of Gender in the Writing of Medieval Catalan History," La Corónica 32 (2004): 35-48.

CANALS, Antoni. Libre anomenat Valeri Maximo dels dits y fets me- 
morables. Traducció catalana del XTV segle per frare Antoni Canals. 2 vols. Ed. R. Miquel y Planas. Barcelona, rir4.

Coroleu y Juglada, José, and José Pella y Forgas, Las cortes catalanas. Estudio juridico y comparativo de su organización. $2 \mathrm{~d}$ ed. Barcelona: Imprenta de la Revista Histórica Latina, 1876.

Coromines, Joan, Josep Gutsoy and Max CAHner, eds. Diccionari etimòlogic i complementari de la llengua catalana. [DECLC]. 9 vols. Barcelona: Curial Edicions Catalanes, 1995.

EAREnfight, Theresa. "The Political Dynamic between the Aragonese Monarchy and the Consell de Cent of Barcelona during the Lieutenancy of María of Castile (1440-1458)." El món urbà a la Corona d'Aragó del 1137 als decrets de Nova Planta. 3 vols. Barcelona: Universitat de Barcelona, 2003. 3: 245-64.

- Queenship, Politics, and Government in the Medieval Crown of Aragon: The Lieutenancy of Maria of Castile, I420-23 and 1432-53. Unpublished doctoral dissertation. Fordham University, New York, NY. 1997.

"María of Castile, Ruler or Figurehead? A Preliminary Study in Aragonese Queenship." Mediterranean Studies 4 (1994): 45-62.

HuNEYCUTT, Lois L. "Intercession and the High-Medieval Queen: The Esther Topos." Power of the Weak. Studies on Medieval Women. Eds. Jennifer Carpenter and Sally-Beth MacLean. Urbana: University of Illinois Press, 1995.

- "Images of Queenship in the High Middle Ages." Haskins Society Journal: Studies in Medieval History I (1989): 6I-7I.

MASSÓ i TORRENTS, Jaime. "Inventari dels bens mobles del rey Martí d'Aragó." Revue Hispanique 12 (1905): 413-590.

PARSONS, John Carmi. "Family, Sex, and Power: The Rhythms of Medieval Queenship." Medieval Queenship. Ed. John C. Parsons. NY: St. Martin's Press, 1993. I-II.

"The Queen's Intercession in Thirteenth-Century England." Power of the Weak. Ed. Jennifer Carpenter. Urbana: University of Illinois Press, 1995. 148-77.

PRINCE, Dawn. "A Reappraisal of the Correspondence of Violant de Bar (1365-I43I)." Catalan Review 8 (1994): 295-3I2.

RYDER, Alan. The Kingdom of Naples under Alfonso the Magnanimous, The Making of a Modern State. Oxford: Clarendon Press, 1976.

Silleras FERnÁNDEZ, Núria. "Widowhood and Deception: Ambiguities of Queenship in Late Medieval Crown of Aragon." In Mark Crane, et al, eds., Shell Games: Scams, Frauds and Deceits (5300-1650), (Toronto: CRRS Publications, University of Toronto, 2004): 185-207.

-. "Queenship en la Corona de Aragón en la Baja Edad Media: estudio y propuesta 
terminológica." La Corónica. A Journal of Medieval Spanish Language and Literature 32.1 (2003): 119-133.

- María de Luna. Una reina entre la piedad y el poder. Unpublished doctoral dissertation. Universitat Autònoma de Barcelona, Spain. 2002.

TASIS i MARCA, Rafael. Joan I. El rei caçador $i$ músic. Bercelona: Editorial Aedos, 1959 . 